\title{
Electronic Customer Relationship Management (E-CRM) Untuk Sistem Pengaduan Pencemaran Lingkungan (Studi Kasus Dinas Lingkungan Hidup Kota Bandar Lampung)
}

\author{
Ihwan Nurdin \\ Institut Informatika dan Bisnis Darmajaya \\ Ihwan.1611050120@mail.darmajaya.ac.id
}

\begin{abstract}
At this time, if the public wants to make a complaint regarding environmental pollution, be it garbage or waste, the community must come directly to the Environmental Service of Bandar Lampung City. Regarding the complaint system which is still simple or not based on the network, it will take time and money to make complaints. In this case, it will be more effective and efficient if the complaint system is used as a website-based complaint system and mobile application that is connected to the internet. Therefore, the author makes Electronic Customer Relationship Management (E-CRM) for the Environmental Pollution Complaint System Case Study of the Bandar Lampung City Environmental Service in order to facilitate the public in complaining about environmental pollution problems.
\end{abstract}

Keyword: E-CRM; Environmental Pollution; Website; Application.

\begin{abstract}
Abstrak
Pada saat ini jika masyarakat ingin melakukan pengaduan terkait pencemaran lingkungan baik itu sampah maupun limbah, masyarakat harus datang langsung ke Dinas Lingkungan Hidup Kota Bandar Lampung. Terkait dengan sistem pengaduan yang masih sederhana atau belum berbasis jaringan tersebut maka akan memakan waktu dan biaya untuk melakukan pengaduan. Dalam hal ini akan lebih efektif dan efisien jika sistem pengaduan tersebut dijadikan sistem pengaduan berbasis website dan aplikasi mobile yang terkoneksi dengan internet. Maka dari itu penulis membuat Electronic Customer Relationship Management (E-CRM) Untuk Sistem Pengaduan Pencemaran Lingkungan Studi Kasus Dinas Lingkungan Hidup Kota Bandar Lampung guna memudahkan masyarakat dalam mengadukan masalah pencemaran lingkungan.
\end{abstract}

Kata kunci: E-CRM; Pencemaran lingkungan; Website; Aplikasi.

\section{PENDAHULUAN}

Menurut Peraturan Daerah Provinsi Lampung Nomor 1 Tahun 2010 Tentang Rencana Ruang Provinsi Lampung Tahun 2009-2029 Kota Bandar Lampung adalah salah satu dari 15 Kabupaten / Kota yang ada di Provinsi Lampung yang mempunyai kedudukan sebagai ibu kota Provinsi Lampung, memiliki luas wilayah 296,00 km² yang terdiri dari 20 kecamatan dan 126 kelurahan/desa, dengan jumlah penduduk 1.175.397 jiwa. Jumlah penduduk tersebut belum termasuk penduduk luar daerah yang bertempat di Kota Bandar Lampung untuk menuntut ilmu maupun bekerja.

Berdasarkan data milik (Dinas Lingkungan Hidup Kota Bandar Lampung, 2019) jumlah sampah di Kota Tapis Berseri mencapai 840 ton per hari dan 35 ton per jam. Dengan beragam jenis sampah dan limbah yang dihasilkan, apabila tidak segera dilakukan penanganan yang tepat dan cepat, maka akan menimbulkan berbagai masalah sehingga resiko terganggunya masalah kesehatan di masyarakat dan sekitarnya. 
Belum adanya pelaporan secara online yang bisa mempermudah masyarakat dalam melaporkan masalah pencemaran lingkungan yang terjadi, dengan objek penelitian berupa sampah organik, sampah anorganik, limbah industri, limbah domestik, limbah pertanian, dan limbah pertambangan. Ketika terjadi masalah pencemaran lingkungan, masyarakat harus mengirimkan surat kepada Dinas Lingkungan Hidup Kota Bandar Lampung untuk melaporkan masalah pencemaran lingkungan, baik sampah dan limbah yang dibuang sembarangan maupun bau yang dihasilkan dari tumpukkan sampah dan limbah tersebut, dan tentunya hal ini akan menghabiskan waktu dan tenaga, karena waktu yang dibutuhkan dalam penanganan hal ini masih memakan waktu yang cukup lama, apalagi di era pandemi covid-19 yang mengaruskan masyarakat untuk tetap berada di dalam rumah. Sehingga masyarakat menginginkan adanya kemudahan layanan yang lebih efisien dan efektif. Sarana penyampaian kritik dan saran yang tidak mencerminkan penilaian kepuasan masyarakat yang menyebabkan tidak terukurnya kepuasan masyarakat terhadap pelayanan dari Dinas Lingkungan Hidup Kota Bandar Lampung.

\section{KERANGKA TEORI}

\subsection{Pencemaran Lingkungan dan Limbah}

Menurut (Wikipedia, 2021) Pencemaran lingkungan didefinisikan sebagai perubahan faktor abiotik akibat kegiatan yang melebihi ambang batas toleransi ekosistem biotik. Misalnya saja penggunaan kendaraan bermotor ataupun alat pengolah bahan baku yang terkadang tidak sesuai dengan standarisasi lingkungan. Jenis-jenis pencemaran lingkungan adalah sebagai berikut: Pencemaran air, Pencemaran udara, Pencemaran tanah, Pencemaran logam berat, dan Pencemaran suara. Sedangkan limbah Menurut (Wikipedia, 2020) adalah buangan yang dihasilkan dari suatu proses produksi baik industri maupun domestik (rumah tangga).

\subsection{Object Oriented Analysis and Design}

Analisis dan desain berorientasi objek adalah metode dalam memikirkan suatu masalah dengan menggunakan model yang dibuat menurut konsep sekitar dunia nyata. Dasar pembuatan adalah objek, yang merupakan kombinasi antara struktur data dan perilaku dalam satu entitas. Konsep OOAD mencakup analisis dan desain sebuah sistem dengan pendekatan objek, yaitu analisis berorientasi objek (OOA) dan desain berorientasi objek (OOD). Analisis berorientasi objek (OOA) berfokus kepada apa yang dilakukan sistem. Sedangkan desain berorientasi objek (OOD) tentang bagaimana sistem melakukannya. (Munawar, 2018)

\subsection{Electronic Customer Relationship Management (E-CRM)}

E-CRM adalah CRM yang diterapkan secara elektronik dengan menggunakan web browser, internet, dan media elektronik lain seperti email, call center, serta personalisasi. E-CRM juga disebut sebagai salah satu teknik bagi perusahaan yang dilakukan secara online untuk mempererat hubungan antara perusahaan dengan para konsumennya. Hal ini bertujuan untuk meningkatkan kepuasan konsumen agar mendapatkan loyalitas dari para konsumennya dan juga dapat meningkatkan kualitas perusahaan tersebut baik dari segi pemasaran maupun produksi. (Bintang et al., 2016).

\section{METODOLOGI}

Metode pengembangan sistem yang digunakan pada penelitian ini adalah rational unified process (RUP). Menurut (A.S, Rosa \& Shalahuddin, 2015) unified process atau dikenal juga proses iteratif dan incremental merupakan sebuah proses pengembangan perangkat lunak yang dilakukan secara iteratif (berulang) dan incremental (bertahap dengan proses menaik). Iteratif bisa dilakukan di dalam setiap tahap, atau iteratif tahap proses pengembangan perangkat lunak 
untuk menghasilkan perbaikan fungsi incremental di mana setiap iterasi akan memperbaiki iterasi berikutnya. Salah satu unified process yang terkenal adalah RUP (Rational Unified Process), RUP menggunakan konsep object oriented dengan aktifitas yang berfokus pada pengembangan model dengan menggunakan Unified Model Language (UML). Rational Unified Process (RUP) memiliki beberapa tahapan yaitu inception, elaboration, construction, dan transition.

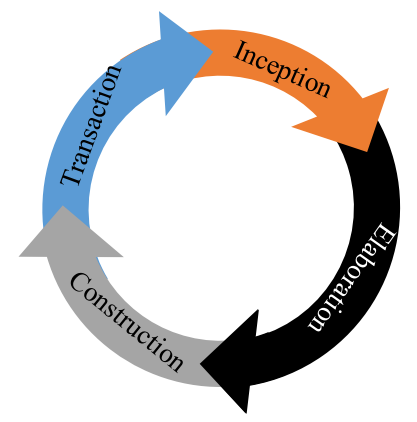

Gambar 1. RUP

\section{HASIL DAN PEMBAHASAN}

Hasil penelitian ini adalah sistem pengaduan pencemaran lingkungan berbasis website dan aplikasi mobile, yang dapat memudahkan masyarakat dalam melaporkan masalah pencemaran lingkungan. Implementasi Electronic Customer Relationship Management (E-CRM) untuk sistem pengaduan pencemaran lingkungan studi kasus Dinas Lingkungan Hidup Kota Bandar Lampung adalah sebagai berikut:

\subsection{Interface user (masyarakat)}

a. Menu pengaduan user (masyarakat)

Berikut ini merupakan capture menu pengaduan pada user (masyarakat). Menu ini ditujukan kepada masyarakat yang ingin mengajukan pengaduan terkait pencemaran lingkungan.

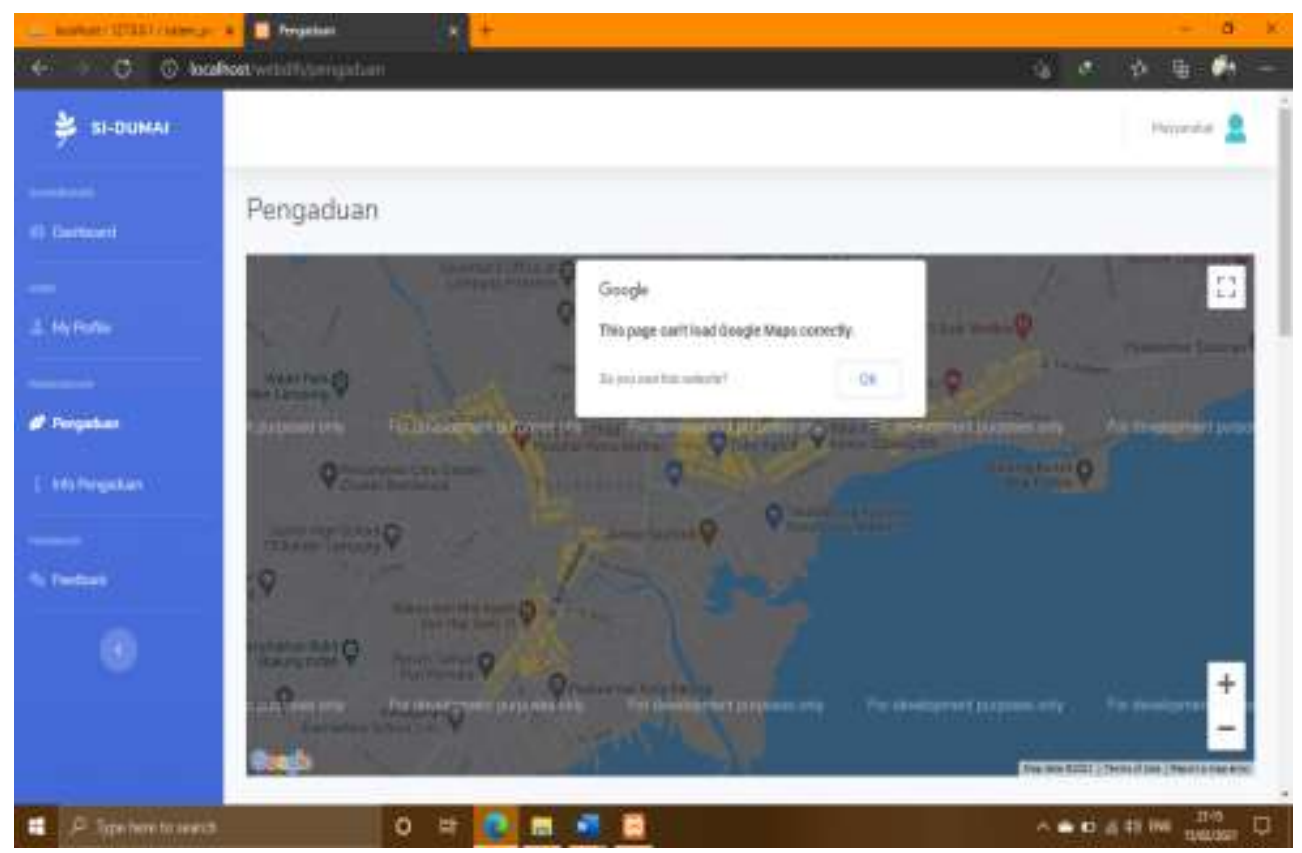




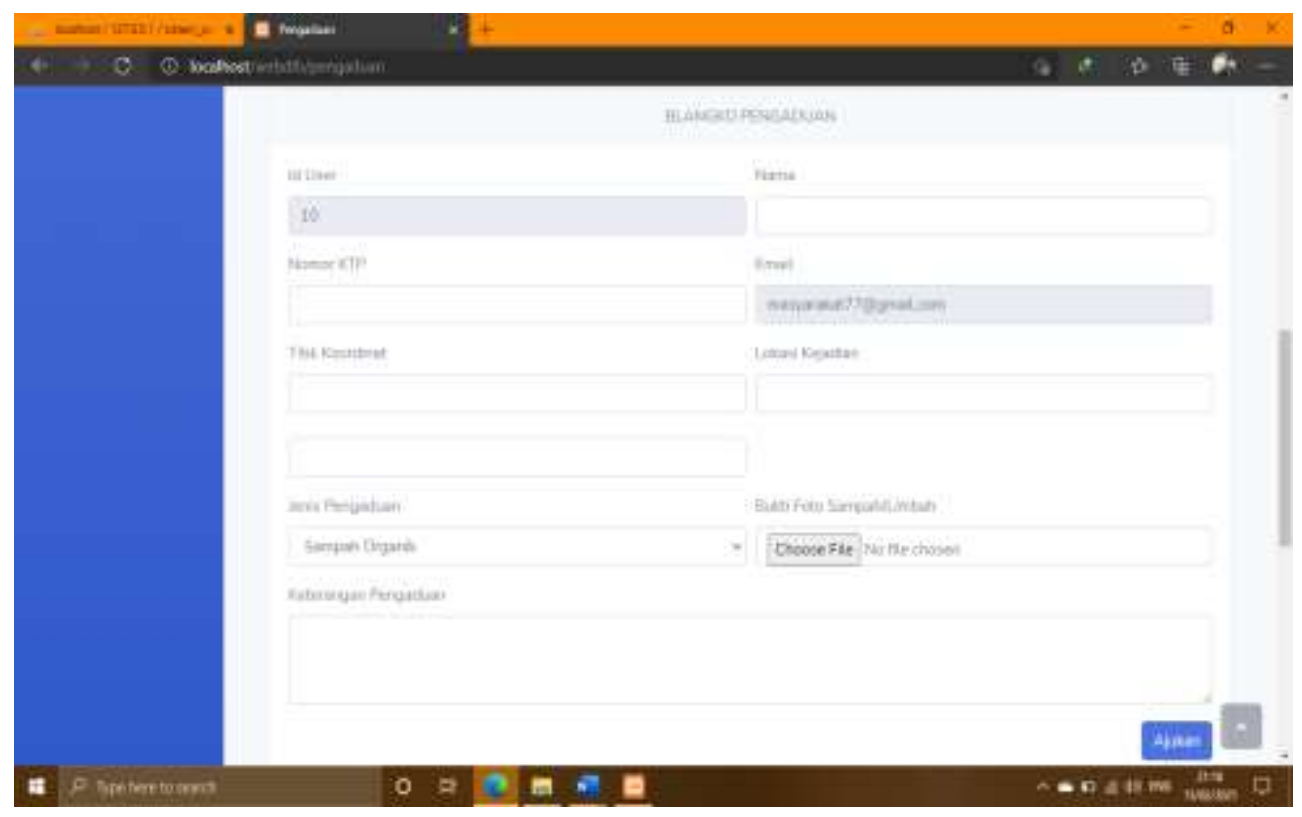

Gambar 2. Tampilan Menu Pengaduan User

b. Menu feedback user (masyarakat)

Berikut ini merupakan capture menu feedback pada user (masyarakat). Menu ini ditujukan kepada masyarakat yang mengakses sistem harus wajib menilai kinerja Dinas Lingkungan Hidup Kota Bandar Lampung.

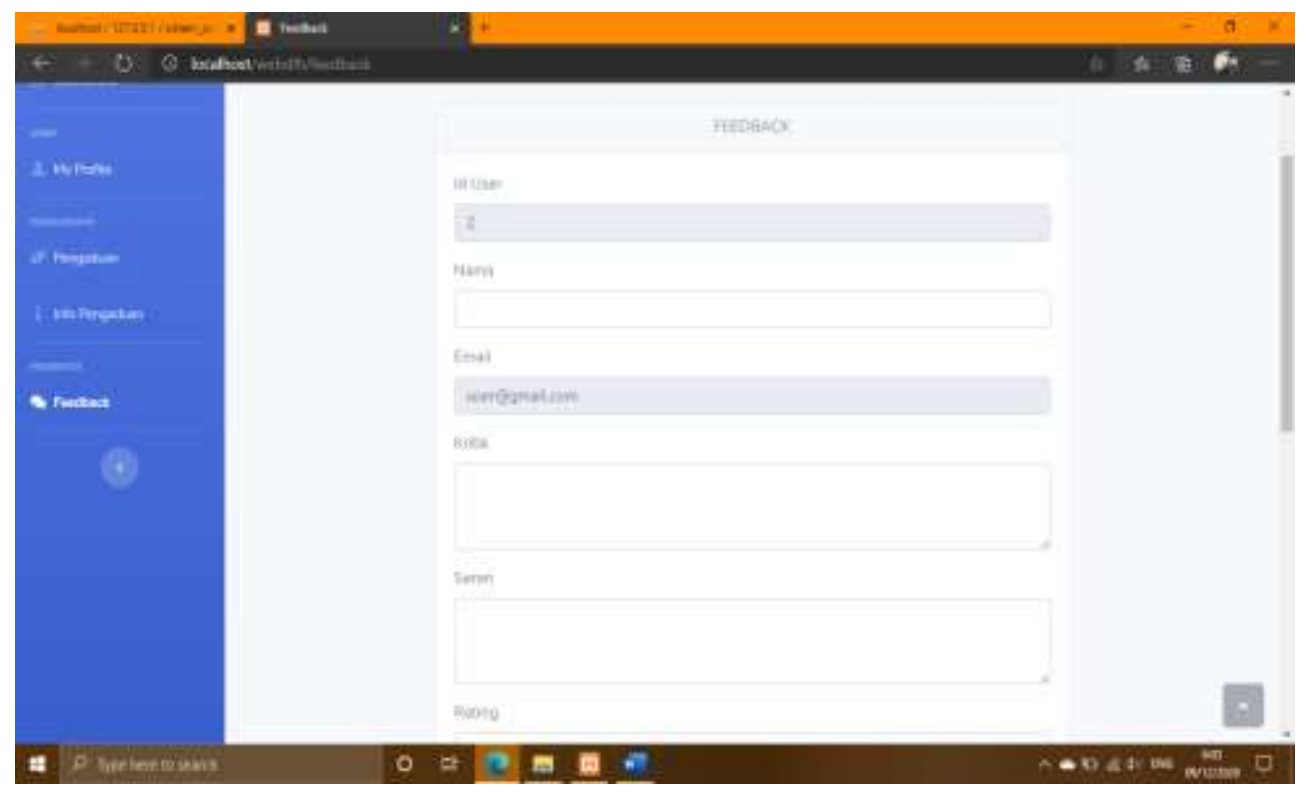

Gambar 3. Tampilan Menu Feedback User

\subsection{Interface admin}

a. Menu data pengaduan admin

Berikut ini merupakan capture menu data pengaduan pada admin. Ini merupakan menu yang dibuat untuk menunjukan informasi mengenai blangko pengaduan yang diajukan oleh user atau masyarakat. 


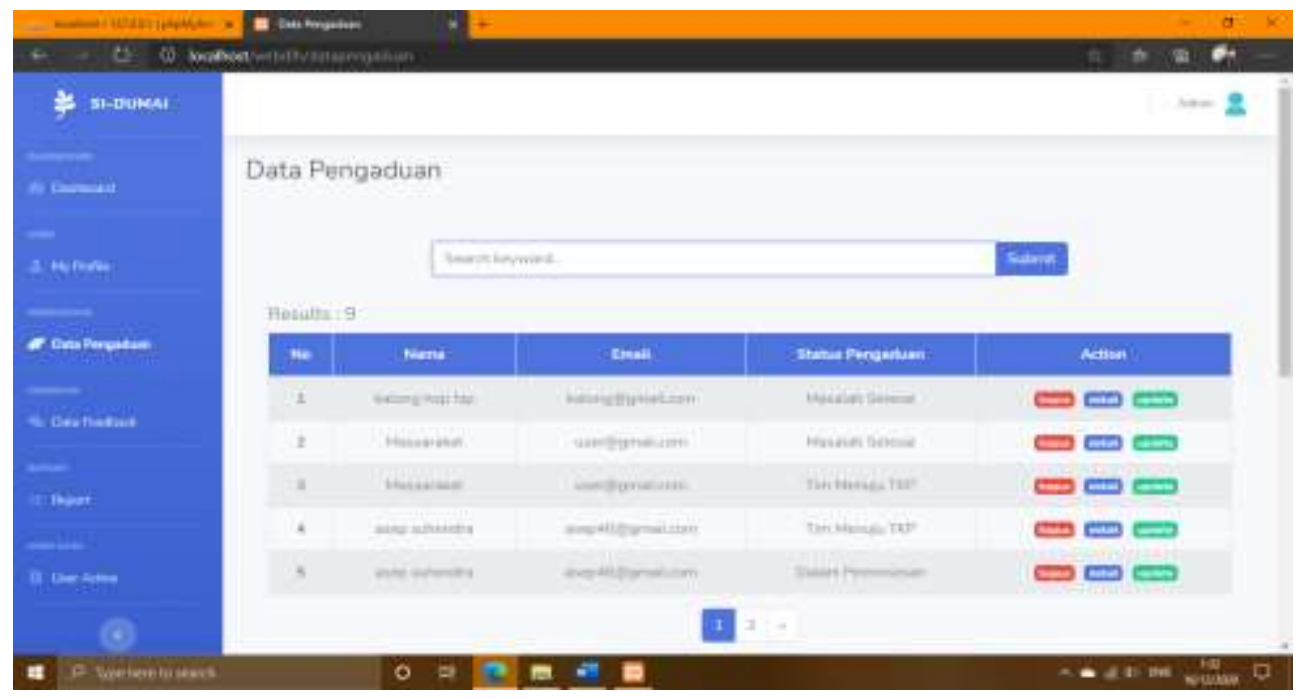

Gambar 4. Tampilan Menu Data Pengaduan Admin

\section{KESIMPULAN}

Berdasarkan hasil pembahasan, maka kesimpulan dari penelitian mengenai "Electronic Customer Relationship Management (E-CRM) Pada Sistem Pengaduan Pencemaran Lingkungan Studi Kasus Dinas Lingkungan Hidup Kota Bandar Lampung" adalah sebagai berikut:

a. E-CRM sistem pengaduan pencemaran lingkungan pada Dinas Lingkungan Hidup Kota Bandar Lampung di rancang untuk memberikan media pelaporan pencemaran lingkungan baik itu penumpukan sampah, limbah produksi maupun limbah rumah tangga. Selain media pelaporan di sini juga tersedia media kritik, saran, dan penilaian/rating (feedback) yang di tujukan terhadap kinerja pelayanan pencemaran lingkungan, dengan adanya kritik, saran, dan rating yang diberikan oleh masyarakat akan menjadikan pertimbangan terhadap pengambilan keputusan untuk kedepanya.

b. Dengan dengan adanya media pengaduan/pelaporan terkait pencemaran lingkungan maka akan menimbulkan dampak secara signifikan yang di rasakan oleh masyarakat antara lain, masyarakat tidak perlu datang langsung ke kantor Dinas Lingkungan Hidup Kota Bandar Lampung untuk mengajukan pengaduan karena sudah ada sistem secara online yang melayani pengaduan tersebut. Dengan mengajukan pengaduan dari rumah maka masyarakat sudah membantu pemerintah memutus rantai penyebaran Covid-19.

Hasil pengujian menggunakan black-box testing menunjukan bahwa kinerja fungsionalitas sistem mampu bekerja dengan baik. Pengujian software dapat dilakukan untuk memvalidasi perilaku sistem dalam menampilkan output berdasarkan kombinasi input yang diberikan. Dengan pengujian menu login, registrasi, pengaduan, dan feedback menunjukan hasil presentasi 100\%, menunjukan bahwa form validation dapat bekerja dengan baik untuk memvalidasi data input maupun output. 


\section{DAFTAR PUSTAKA}

Peraturan Daerah Provinsi Lampung Nomor 1 Tahun 2010 Tentang Rencana Ruang Provinsi Lampung Tahun 20092029 (Lembaran Daerah Provinsi Lampung Tahun 2010 Nomor 1, Tambahan Lembaran Daerah Provinsi Lampung Nomor 346).

Peraturan Daerah Provinsi Lampung Nomor 3 Tahun 2006 Tentang Pengelolaan Sumber Daya Alam dan Lingkungan Hidup.

Dinas Lingkungan Hidup Kota Bandar Lampung. 2019. "Program Pengelolaan Sampah Dengan Memaksimalkan Program Sokli".

https://id.wikipedia.org/wiki/Pencemaran.

https://id.wikipedia.org/wiki/Sampah.

Munawar., 2018. Analisis Perancangan Sistem Berorientasikan Objek dengan UML (Unified Modeling Language). In Bandung: Informatika.

Nugroho, F. E., 2016. Perancangan Sistem Informasi Penjualan Online Studi Kasus Tokoku. Simetris : Jurnal Teknik Mesin, Elektro Dan Ilmu Komputer, 7(2), 717. https://doi.org/10.24176/simet.v7i2.786

Bintang, A., Andriani, R., Rizki, K., \& Dewantara, Y., 2016. Peran E-CRM (Electronic Customer Relationship Management) Dalam Meningkatkan Kualitas Pelayanan (Studi pada Harris Hotel \& Conventions Malang). Jurnal Administrasi Bisnis, 40(1), 194-198.

A.S, R., \& Shalahuddin, M., 2015. Rekayasa Perangkat Lunak Terstruktur dan Berorientasi Objek. Bandung: Informatika. In Jurnal Pilar Nusa Mandiri. 